\title{
HARASSMENT AND BULIYING AMONG STUDENTS IN HIGHER EDUCATION INSTITUTIONS: MANIFESTATION OF SINGLE CASES OF HARASSMENT AND BULIYING IN ASPECTS OF DEMOGRAPHIC VARIABIES
}

\author{
Jolita Vveinhardt ${ }^{1}$, Vilija Bite Fominiene ${ }^{2}$, Regina Andriukaitiene ${ }^{3}$ \\ and Dalia Streimikiene ${ }^{4 *}$ \\ ${ }^{1)}$ Vytautas Magnus University, Kaunas, Lithuania \\ ${ }^{2334)}$ Lithuanian Sports University, Kaunas, Lithuania
}

Please cite this article as:

Vveinhardt, J., Fominiene, V.B., Andriukaitiene, R. and Streimikiene, D., 2019. Harassment and Bullying among Students in Higher Education Institutions: Manifestation of Single Cases of Harassment and Bullying in Aspects of Demographic Variables. Amfiteatru Economic, 21(51), pp. 409-426.

DOI: $10.24818 / \mathrm{EA} / 2019 / 51 / 409$

\section{Article History}

Received: 15 November 2018

Revised:3 February 2019

Accepted: 2 March 2019:

\begin{abstract}
The research goal - to analyse manifestations of single cases of harassment and bullying in students' inter-relationship and to compare them in aspects of socio-demographic variables. 623 students studying at Lithuanian higher education institutions were questioned. We determined a dependence of harassment and bullying on respondents' age: they were experienced more often by 18-30 year-old students, whereas older students' complaints were less. Older students more often requested for active policy of higher education institutions in preventing negative relations. Women showed more initiative in seeking for help, unlike men, experience of negative relations of which was higher in the past. Harassment and bullying were more experienced by the students studying at higher education colleges, unlike those studying at universities. The research results are significant in striving for better perception of impact of harassment and bullying at higher education institutions on demographic variables and negative inter-personal relationship experienced at school age. This knowledge is necessary for higher education institutions preparing and developing a prevention of harassment and bullying.
\end{abstract}

Keywords: harassment, bullying, demographic variables, higher education colleges, universities, students.

JEL Classification: I20, I23, O15, P46

${ }^{*}$ Corresponding author, Dalia Streimikiene - dalia.streimikiene@knf.vu.lt 


Harassment and Bullying among Students in Higher Education Institutions:
Manifestation of Single Cases of Harassment
and Bullying in Aspects of Demographic Variables

\section{Introduction}

Higher education institutions constantly face challenges of diversity management. Studying at higher education institution is selected by students of very different age, different interpersonal relationship, working, learning and other experience, representatives of different ethnic or social groups. That means that the obtained experience and knowledge might determine very different reactions to harassment and bullying and decisions taken, which has to be taken into account by higher education institutions' administrations in striving to ensure safe environment of studies. Students' safety is an important part of higher education institution's policy, which affects not only students' psychological well-being. Bullying is a strong source of stress (Hoel, Zapf and Cooper, 2002) and very negatively affects victim's physical and mental health, it is related to induced depression, anxiety, low self-esteem, loneliness and hopelessness, which might lead to suicide attempts (Hong, Kral and Sterzing, 2014). Harassment and bullying also negatively affect study process, and influence a decision to choose one or another university, taking into account public responses - it is determined that selections of future students depend on how an education institution guaranties safety (Shelley et al., 2017).

Over the last decades there were performed quite a few harassment and bullying studies at work place, i.e. between students and lecturers (e.g., DeSouza, 2010) or between higher education institutions' staff (e.g., Kang and Sidhu, 2015), however, some negative aspects of students' inter-relationship remain as if in a particular grey zone, and perpetrators not always remain identified and punished (Vidu et al., 2014; Valls et al., 2016). Conclusions of some researches on harassment and bullying performed in different cultures highlight that, in striving to ensure students' well-being, prevention policy of education institutions is important in tackling the problems related to bullying, assessing both direct interpersonal relationship and tendencies of rapid spread of bullying in cyberspace (DeSouza and Ribeiro, 2005; Valls et al., 2016; Betts et al., 2016; Myers and Cowie, 2017; etc.). Its importance grows when it's set that persons belonging to more than one disadvantaged groups more often suffer from assaults (Andersson et al., 2017), and some continuity exists, because bullying in childhood is related to aggressive behaviour when the person is an adult already (Sansone, Leung and Wiederman, 2012).

All that indicates both impact of student's experience and wide and sophisticated reasons' spectrum related to individual demographic and social characteristics of a victim, which are important to be considered by the managers of higher education institutions who organize a policy directed against harassment and bullying. It is also very important to assess students' previous bullying experience and differences of the persons choosing different institutions that is colleges and universities.

The research goal is to analyse manifestations of single cases of harassment and bullying in students' inter-relationship and to compare them in aspects of socio-demographic variables.

\section{Review of the scientific literature}

Modern society expects that the graduate of higher education will become its full-fledged member - creative, communicating and cooperating as well as able to tackle efficiently life problems. Young people also expect that higher education studies will affect their future 
and successful career. In striving for these goals, a safe learning environment in higher education also becomes an important component (Chekwa, Thomas Jr. and Jones, 2013), where importance of good socio-psychological climate is highlighted in addition to the physical one (Hagenauer and Volet, 2014). Unfortunately, the researches, although stating endeavour of higher education institutions to create an environment favourable to education, also reveal manifestations of various forms of aggression inside it (Aleid, 2016), where bullying is distinguished as the most dominating aggression form (Piotrowski and King, 2016).

Bullying is a multifaceted phenomenon, spread in a society widely enough. At the same time, it is also a very personal experience of each person (Meriläinen, Puhakka and Sinkkonen, 2015). Such amplitude of the phenomenon also determines its conceptions' diversity that is related to both the research context and the use of the concepts in different cultures and languages. First, bullying can be understood as a repeated form of aggressive behaviour - systematic abuse of power. However, to describe the concept of bullying, the most often used concept is a wider one, explaining that it is "unwanted aggressive behaviour" that "inflicts harm or distress," and is "repeated multiple times or is highly likely to be repeated" in the context of an "observed or perceived power differential" (Patchin and Hinkduja, 2015).

To better understand and research this phenomenon, it is divided into different types and analysed in different contexts. And though bullying can occur in different social settings all around world - school, home, workplace, army, prison or other places (Monks et al., 2009), here it is manifests into both direct and indirect modes. During direct bullying, the victims are being openly threatened, nicknamed, harassed, attacked, beaten, kicked. Meanwhile, indirect bullying is when manipulation of social relationships occurs on purpose to hurt. Also bullying, considering its commonest forms, is divided into physical, verbal, relational or social and cyber. The most common bullying forms, usually ascribed to direct bullying, are physical and verbal bullying. During physical bullying, the bullies use force to cause physical harm to victims. Meanwhile, verbal bullying, as one of the most common forms of bullying, includes acts such as hurtful name-calling, persistent teasing, gossip, and racist or sexual remarks. During such bullying, there are rumours, backbiting spread on purpose to harm (Shaw et al., 2013). Meanwhile, cyber bullying is supposed as one of the most pernicious and contemporary. It is a form of bullying when intentional and repeating damage to person is done through computers, cell phones and other electronic devices (Patchin and Hinduja, 2015).

However, analysing manifestation of these modes and forms of bullying, different peculiarities of their manifestations were determined as well. Direct bullying is common in young children. When a child grows, direct physical bullying gradually changes into verbal, which gradually, when the child takes social understanding, turn into indirect and remains dominant. In dominance of ways and forms of bullying, gender differences are significant as well. Masculine gender is the gender that more often participates in direct and especially direct physical bullying, meanwhile, girls are more implementing indirect or direct verbal bullying (Smith, 2016; Jormanainen et al., 2014; Nishina, Juvonen and Witkow, 2005; etc.).

Since it is recognized that bullying is an extremely negative behaviour, their consequences are painful and determine subsequent emotional and physical state and behaviour of the persons participating. The researches analysing the relation between bullying manifestations and participating persons determined that both victims or bullies, and 
bystanders become at risk for negative future outcomes. Manifestations of bad mental or physical health could be determined by both the level of involvement into bullying and the role taken. Victims of bullying most often suffer from depression, anxiety, suicidal thoughts, apathy, lack of personal satisfaction, feelings of sadness, unhappiness, loneliness or self-esteem, they more often face sleeping difficulties and nervousness. Meanwhile, being a bully can be related to highest use of tobacco, alcohol and drugs in future, criminality (Blood and Blood, 2016; Seixas, Coelho and Nicholas-Fischer, 2013; Monks et al., 2009; etc.).

Analysing bullying and its prevalence in various social contexts, most researches state that involvement in bullying is mainly suffered by children and teenagers. Such understanding determines the abundance of the researches preformed in the environment of primary and secondary schools (Patton et al., 2017). However, recently, with emphasis that bullying does not disappear with humans' age, there is more and more interest in bullying existence in higher education, by recognizing it as a sensitive and still unsolved problem (Kyriacou, Mylonakou-Keke and Stephens, 2016). In this context, though recognizing the lack of researches (Lund and Ross, 2016), bullying is examined by analysing both the relationship between lecturers and students, and employees' relationship, and analysing the relationship between students (Marraccini, Weyandt and Rossi, 2015; Perry and Blincoe, 2015; Sinkkonen, Puhakka and Meriläinen, 2014; Serinkan et al., 2013; etc.). These researches can be performed by using different measures, such as questionnaires, interviews, diaries, observations that rely on different informants (Van Noorden et al., 2015). However, while analysing bullying and its prevalence in higher education, self-report assessment is applied most often, which helps to determine various bullying and victimization experiences. Manifestation of bullying and harassment in relationship is determined from descriptions of students' verbal and non-verbal communication, academic abuse (Palaz, 2013, Celik and Bayraktar, 2004), behaviour of persons suffering from bullying and harassment (Cooper et al., 2011) or damage suffered (Pickel and Gentry, 2017). The researches often analyse persons' experience in childhood or at other education institutions (Holt et al., 2014; Adams and Lawrence, 2011; Pontzer, 2010). The results of these researches are interpreted with reference to both various cultural or socio-economic factors, education policies or implemented intervention programmes, and various socio-demographic characteristics of the researched persons (Porhola et al., 2016; Meriläinen, Puhakka and Sinkkonen, 2015). Age, gender, ethnic origin, study course also might become significant factors in explanation of quantitative manifestations of bullying and harassment in the context of higher education (Goodboy, Martin and Goldman, 2016; Pontzer, 2010).

The results of the researches that indicate existence of the phenomenon in higher education, often point out not only various negative psychosocial outcomes to participants of bullying process. Alongside the phenomena such as use of alcohol or drugs, suicidal ideation, panic attacks, stress and others (Birks et al., 2018; Cao, Wei and Cai, 2017; Jantzer and Cashel, 2017; Rospenda et al., 2014; etc.) a decision of the students who suffered bullying to leave higher education institution is also pointed out (Cornell et al., 2013). In striving to avoid various negative consequences and ensure students' well-being, it is important not only to declare such negative behaviour, but also to look for efficient ways of solving the problem. To this end, institutions of higher education increasingly provide various prevention or intervention programs, which are directed towards reduction of aggressiveness in higher education. Unfortunately, a considerable number of such programmes or single measures 
are based on presumptions based on the researches performed in the context of secondary or primary education (Glass and Fireman, 2016). One of the reasons is a lack of the researches performed in the context of higher education.

\section{Research methodology}

The research instrument - questionnaire Bullying and Single Cases of Harassment in Higher Education Institutions (B-SCH-St) which consists of 10 dimensions covering 42 items: communication (4 items, covering the character of student's inter-communication in higher education institution: harassing, ignoring, threatening, etc.), personal reputation (4 items, covering critics of personal features, values, etc.), student's reputation (4 items, covering the person's reputation of a student by hiding important information, criticizing performed work, etc.), experienced harm (5 items, covering worsening health, worsening work results, stolen ideas and works, etc.), experiences at school (4 items that aim at determining current students' experiences brought from school in the aspect of pupil's destructive inter-relationship), reaction and behaviour (7 items, describing students' personal reaction and behaviour regarding students' destructive inter-relationship), possible and existing intervention measures in higher education institution ( 8 items revealing students' opinion what measures would help to avoid abusive inter-relation among students and 1 question, aimed at students' proposals what could be done so that such abusive relationship would be avoided at the institution of higher education) and 2 questions, directly related to the topic being analysed (action of persons who were appealed for help and single case of harassment and bullying dimensions) and 6 questions related to information about the student. Internal consistency (Cronbach's Coefficient Alpha) for all dimensions satisfy the major validity conditions raised for questionnaires because the lowest value is 0.69 , the highest - 0.88 (Vveinhardt et al, 2017; Vveinhardt et al., in press).

During the research 623 students from two types of Lithuanian higher education institutions (9 universities and 9 higher education colleges) were questioned. Among respondents was 67.6 percent women $(\mathrm{N}=421)$ and 32.4 percent men $(\mathrm{N}=202), 33.1$ percent was from higher education colleges and 66.9 percents from universities. The greater part of the respondents indicated that they are 21-25 year old $(\mathrm{N}=332)$. Others social demographic characteristics of the persons under research together with the research results are presented in Tables no. 1-3.

The data collection procedure was realized in the months September-November of the year 2017 in Lithuanian higher education institutions. The autors were responsible for the data collection and participation was entirely voluntary, confidential and anonymous.

Statistical analysis of the research data was carried out using SPSS (Statistical Package of the Social Science) version 20.0. The following parameters were calculated: chi-square criterion, applying cross-tabs and Kruskal Wallis H criterion.

\section{Research results}

During the research, while sorting out whether bullying exists in inter-relationship of higher education institutions' students, it was determined that $81.54 \%$ of respondents $(\mathrm{N}=508)$ stated that they are not experiencing bullying. However, $18.46 \%$ of the persons under research $(\mathrm{N}=115)$ are experiencing bullying. They are often suffered by $1.6 \%(\mathrm{~N}=10)$ of 
respondents, and $17.82 \%(\mathrm{~N}=105)$ suffer bullying, but occasionally. The research results through seven dimensions were compared considering such criteria: students' age, gender, higher education institution's type and study cycle.

Table no. 1: Distribution of answers of students experiencing single cases of harassment and bullying in inter-personal relationship, in regard to age groups and dimensions

\begin{tabular}{|c|c|c|c|c|c|c|c|c|c|}
\hline \multirow{3}{*}{ Dimensions } & $\begin{array}{c}18-20 \\
\text { year } \\
\text { old } \\
\end{array}$ & $\begin{array}{c}21-25 \\
\text { year } \\
\text { old } \\
\end{array}$ & $\begin{array}{c}26-30 \\
\text { year } \\
\text { old } \\
\end{array}$ & $\begin{array}{c}31-35 \\
\text { year } \\
\text { old } \\
\end{array}$ & $\begin{array}{c}36-45 \\
\text { year } \\
\text { old } \\
\end{array}$ & \multirow{2}{*}{\multicolumn{2}{|c|}{$\begin{array}{l}\text { Chi-square } \\
\text { verification } \\
\text { results }\end{array}$}} & \multirow{2}{*}{\multicolumn{2}{|c|}{$\begin{array}{l}\text { Kruskal- } \\
\text { Wallis } \\
\text { H } \\
\text { verification } \\
\text { results }\end{array}$}} \\
\hline & \multirow[t]{2}{*}{$\begin{array}{l}N= \\
158\end{array}$} & \multirow[t]{2}{*}{$\begin{array}{l}\mathrm{N}= \\
332\end{array}$} & \multirow[t]{2}{*}{$\mathrm{N}=47$} & \multirow[t]{2}{*}{$\mathrm{N}=44$} & \multirow[t]{2}{*}{$\mathrm{N}=42$} & & & & \\
\hline & & & & & & $X^{2}$ & $\mathrm{p}$ & $X^{2}$ & $\mathrm{p}$ \\
\hline \multirow{2}{*}{$\begin{array}{l}\text { Communi- } \\
\text { cation }\end{array}$} & $42.6 \%$ & $36.7 \%$ & $41.1 \%$ & $20.5 \%$ & $21.4 \%$ & 11.234 & $0.024 *$ & - & - \\
\hline & 328.22 & 314.44 & 324.07 & 260.76 & 271.86 & - & - & 9.809 & 0.044* \\
\hline \multirow{2}{*}{$\begin{array}{l}\text { Personal } \\
\text { reputation }\end{array}$} & $33.5 \%$ & $32.8 \%$ & $27.3 \%$ & $25.5 \%$ & $21.4 \%$ & 3.695 & 0.449 & - & - \\
\hline & 324.45 & 315.17 & 296.97 & 290.05 & 279.92 & - & - & 4.715 & 0.318 \\
\hline \multirow{2}{*}{$\begin{array}{l}\text { Student's } \\
\text { reputation }\end{array}$} & $35.4 \%$ & $34.6 \%$ & $34.0 \%$ & $23.8 \%$ & $25.0 \%$ & 3.667 & 0.453 & - & - \\
\hline & 320.10 & 316.05 & 311.59 & 279.70 & 283.82 & - & - & 4.197 & 0.380 \\
\hline \multirow{2}{*}{$\begin{array}{l}\text { Experienced } \\
\text { harm }\end{array}$} & $27.7 \%$ & $32.5 \%$ & $26.6 \%$ & $18.2 \%$ & $21.4 \%$ & 6.179 & 0.186 & - & - \\
\hline & 308.58 & 323.46 & 303.56 & 272.70 & 284.87 & - & - & 7.147 & 0.128 \\
\hline \multirow{2}{*}{$\begin{array}{l}\text { Intervention } \\
\text { measures }\end{array}$} & $67.2 \%$ & $68.4 \%$ & $81.0 \%$ & $74.5 \%$ & $77.3 \%$ & 9.722 & $0.044 *$ & - & - \\
\hline & 292.18 & 302.24 & 368.24 & 344.26 & 366.98 & - & - & 12.841 & $0.012 *$ \\
\hline \multirow{2}{*}{$\begin{array}{l}\text { Experience } \\
\text { at school }\end{array}$} & $32.9 \%$ & $26.8 \%$ & $34.0 \%$ & $29.5 \%$ & $21.4 \%$ & 3.704 & 0.448 & - & - \\
\hline & 323.93 & 312.52 & 333.64 & 279.69 & 272.63 & - & - & 4.839 & 0.304 \\
\hline \multirow{2}{*}{$\begin{array}{l}\text { Reaction } \\
\text { and } \\
\text { behaviour }\end{array}$} & $74.5 \%$ & $75.0 \%$ & $72.9 \%$ & $81.0 \%$ & $76.6 \%$ & 1.739 & 0.784 & - & - \\
\hline & 304.98 & 310.47 & 294.22 & 335.94 & 345.31 & - & - & 3.003 & 0.557 \\
\hline
\end{tabular}

Notes: * -statistical significance level $\alpha=0.05 ; * *$ - statistical significance level $\alpha=0.01$.

$$
\text { R.v. - average of ranks. }
$$

The number of students experiencing single cases of harassment and bullying in interpersonal relationship, in some aspects significantly differs depending on age (5 age groups distinguished). Verified by chi-square criterion, applying cross-tabs and Kruskal Wallis $H$ criterion, Table no. 2 presents the percentage of respondents' assent and ranks' averages calculated from total sum of points. All statements were coded as negative, therefore, the higher the value, the higher respondents' assent to distinguished statements. Accentuated value of reliability $p$ indicates statistically significant differences, in this case, in two dimensions, i.e. in the dimensions „Communication” and „Intervention measures”. When percentage or average are very similar to each other, in the sample of this research (and in a particular dimension), then the determined difference is small and, therefore, $p$ in such 
cases does not indicate statistically significant differences. Statistically significant $p$ signifies that differences would be recorded in case not only of this, but of another sample as well.

Analysing the communication dimension, it became clear that communication in younger age groups (18-30 years) is more complicated than in older age groups (31-35 and 36-45 years). That means, the number of negative responses recorded in the students' group of age up to 30 years was almost double.

Respondents' responses recorded in the dimension of intervention measures indicate that the need for such measures is more highlighted in the age groups from 26 to 45 years. Students representing the groups of 18-20 and 21-25 years are less categorical than the persons belonging to older age groups. In this dimension, negative-positive responses are less significant than in the dimension "Communication".

Table no. 2: Distribution of answers of students, experiencing single cases of harassment and bullying in inter-personal relationship, in regard to gender and dimensions

\begin{tabular}{|c|c|c|c|c|c|c|c|}
\hline \multirow[t]{2}{*}{ Dimensions } & \multirow[t]{2}{*}{$\begin{array}{l}\text { Women } \\
\mathrm{N}=421\end{array}$} & \multirow[t]{2}{*}{$\begin{array}{c}\text { Man } \\
\mathrm{N}=202\end{array}$} & \multicolumn{2}{|c|}{$\begin{array}{l}\text { Chi-square } \\
\text { verification } \\
\text { results } \\
\end{array}$} & \multicolumn{3}{|c|}{$\begin{array}{c}\text { Mann-Whitney U } \\
\text { verification } \\
\text { results } \\
\end{array}$} \\
\hline & & & $X^{2}$ & $\mathrm{p}$ & $\mathrm{U}$ & $\mathrm{Z}$ & $\mathrm{p}$ \\
\hline \multirow{2}{*}{ Communication } & $37.1 \%$ & $34.2 \%$ & 0.496 & 0.481 & - & - & - \\
\hline & 312.77 & 310.40 & - & - & 42198.0 & -0.179 & 0.858 \\
\hline \multirow{2}{*}{$\begin{array}{l}\text { Personal } \\
\text { reputation }\end{array}$} & $31.2 \%$ & $31.4 \%$ & 0.002 & 0.967 & - & - & - \\
\hline & 310.25 & 315.65 & - & - & 41784.5 & -0.427 & 0.670 \\
\hline \multirow{2}{*}{$\begin{array}{l}\text { Student's } \\
\text { reputation }\end{array}$} & $32.3 \%$ & $35.6 \%$ & 0.685 & 0.408 & - & - & - \\
\hline & 307.18 & 322.04 & - & - & 40493.5 & -1.153 & 0.249 \\
\hline \multirow{2}{*}{$\begin{array}{l}\text { Experienced } \\
\text { harm }\end{array}$} & $28.3 \%$ & $30.2 \%$ & 0.248 & 0.618 & - & - & - \\
\hline & 308.86 & 318.55 & - & - & 41198.0 & -0.788 & 0.431 \\
\hline \multirow{2}{*}{$\begin{array}{l}\text { Intervention } \\
\text { measures }\end{array}$} & $72.4 \%$ & $63.9 \%$ & 4.761 & 0.029* & - & - & - \\
\hline & 325.68 & 283.49 & - & - & 36761.0 & -2.742 & $0.006 * *$ \\
\hline \multirow{2}{*}{$\begin{array}{l}\text { Experience at } \\
\text { school }\end{array}$} & $25.7 \%$ & $35.1 \%$ & 6.010 & $0.014 *$ & - & - & - \\
\hline & 301.34 & 334.23 & - & - & 38031.5 & -2.143 & 0.032* \\
\hline \multirow{2}{*}{$\begin{array}{l}\text { Reaction and } \\
\text { behaviour }\end{array}$} & $77.9 \%$ & $67.8 \%$ & 7.339 & $0.007 * *$ & - & - & - \\
\hline & 328.18 & 278.28 & - & - & 35709.5 & -3.274 & $0.001 * *$ \\
\hline
\end{tabular}

Notes: * - statistical significance level $\alpha=0.05 ; * *$ - statistical significance level $\alpha=0.01$. R.v. - average of ranks.

The number of students experiencing single cases of harassment and bullying in inter-personal relationship, in some aspects significantly differs depending on gender, i.e. statistically 
significant differences were recorded in three dimensions. Verified by chi-square criterion, applying cross-tabs and using Mann-Whitney $U$ test (table no. 3). The results of the dimension "Intervention measures" indicate, that female (students) position regarding the need for intervention measures at higher education institutions is expressed stronger than that of male (students). The results of the dimension „Experience at school” indicate that men (students) had more negative experience at school than women (students). That means, male students state that they experienced more bullying at school, saw more cases of bullying, when they kept out of the conflict in order to avoid suffering, or just paid no attention. However, in the dimension „Reaction and behaviour” it is highlighted that women are more applying for help regarding single cases of harassment and bullying in inter-relationship than men. It can be stated that such results could be conditioned by social constructs related to behaviour (in this case a reaction to negative behaviour) norms based on sexuality.

Table no. 3: Distribution of answers of students experiencing single cases of harassment and bullying in inter-personal relationship, in regard to type of higher education institution and dimensions

\begin{tabular}{|c|c|c|c|c|c|c|c|}
\hline \multirow{2}{*}{ Dimensions } & $\begin{array}{l}\text { Higher } \\
\text { education } \\
\text { college } \\
\end{array}$ & $\begin{array}{l}\text { Univer- } \\
\text { sity }\end{array}$ & \multicolumn{2}{|c|}{$\begin{array}{l}\text { Chi-square } \\
\text { verification } \\
\text { results }\end{array}$} & \multicolumn{3}{|c|}{$\begin{array}{c}\text { Mann-Whitney U } \\
\text { verification } \\
\text { results }\end{array}$} \\
\hline & & & $X^{2}$ & $\mathrm{p}$ & $\mathrm{U}$ & $\mathrm{Z}$ & $\mathrm{p}$ \\
\hline \multirow{2}{*}{$\begin{array}{l}\text { Communica- } \\
\text { tion }\end{array}$} & $35.0 \%$ & $36.7 \%$ & 0.181 & 0.671 & - & - & - \\
\hline & 311.01 & 312.49 & - & - & 42748.0 & -0.112 & 0.911 \\
\hline \multirow{2}{*}{$\begin{array}{l}\text { Personal } \\
\text { reputation }\end{array}$} & $27.7 \%$ & $33.1 \%$ & 1.886 & 0.17 & - & - & - \\
\hline & 302.97 & 316.46 & - & - & 41091.5 & -1.072 & 0.284 \\
\hline \multirow{2}{*}{$\begin{array}{l}\text { Student's } \\
\text { reputation }\end{array}$} & $32.0 \%$ & $34.1 \%$ & 0.251 & 0.616 & - & - & - \\
\hline & 306.82 & 314.56 & - & - & 41884.5 & -0.603 & 0.546 \\
\hline \multirow{2}{*}{$\begin{array}{l}\text { Experienced } \\
\text { harm }\end{array}$} & $25.2 \%$ & $30.7 \%$ & 1.995 & 0.158 & - & - & - \\
\hline & 301.16 & 317.35 & - & - & 40718.5 & -1.323 & 0.186 \\
\hline \multirow{2}{*}{$\begin{array}{l}\text { Intervention } \\
\text { measures }\end{array}$} & $69.4 \%$ & $69.8 \%$ & 0.009 & 0.925 & - & - & - \\
\hline & 311.75 & 312.12 & - & - & 42900.0 & -0.024 & 0.981 \\
\hline \multirow{2}{*}{$\begin{array}{l}\text { Experience } \\
\text { at school }\end{array}$} & $32.0 \%$ & $27.1 \%$ & 1.644 & 0.200 & - & - & - \\
\hline & 313.89 & 311.06 & - & - & 42561.0 & -0.185 & 0.853 \\
\hline \multirow{2}{*}{$\begin{array}{l}\text { Reaction } \\
\text { and } \\
\text { behaviour }\end{array}$} & $69.9 \%$ & $77.0 \%$ & 3.647 & $0.046^{*}$ & - & - & - \\
\hline & 291.84 & 321.96 & - & - & 38798.5 & -1.986 & $0.047 *$ \\
\hline
\end{tabular}

Notes: * - statistical significance level $\alpha=0.05 ; * *$ - statistical significance level $\alpha=0.01$. R.v. - average of ranks. 
The number of students experiencing single cases of harassment and bullying in interpersonal relationship, in one aspect (out of seven analysed) significantly differs depending on the type of higher education institution. Verified by chi-square criterion, applying crosstabs and using Mann-Whitney $U$ test (table no. 4).

Table no. 4: Distribution of answers of students experiencing single cases of harassment and bullying in inter-personal relationship, in regard to study cycle and dimensions

\begin{tabular}{|c|c|c|c|c|c|c|c|}
\hline \multirow{2}{*}{ Dimensions } & $\begin{array}{c}1 \text { cycle } \\
\text { Bachelor } \\
\mathrm{N}=543\end{array}$ & $\begin{array}{l}2 \text { cycle } \\
\text { Master } \\
\mathrm{N}=80\end{array}$ & \multicolumn{2}{|c|}{$\begin{array}{l}\text { Chi-square } \\
\text { verification } \\
\text { results }\end{array}$} & \multicolumn{3}{|c|}{$\begin{array}{c}\text { Mann-Whitney } U \\
\text { verification } \\
\text { results }\end{array}$} \\
\hline & $\%$ & $\%$ & $\mathbf{X}^{2}$ & $\mathbf{p}$ & $\mathbf{U}$ & $\mathbf{Z}$ & $\mathbf{p}$ \\
\hline \multirow{2}{*}{$\begin{array}{l}\text { Communica- } \\
\text { tion }\end{array}$} & $36.6 \%$ & $32.5 \%$ & 0.520 & 0.471 & - & - & - \\
\hline & 315.54 & 287.97 & - & - & 19797.5 & -1.492 & 0.136 \\
\hline \multirow{2}{*}{$\begin{array}{l}\text { Personal } \\
\text { reputation }\end{array}$} & $32.6 \%$ & $22.5 \%$ & 3.376 & 0.049* & - & - & - \\
\hline & 316.75 & 279.75 & - & - & 19140.0 & -2.092 & $0.036 *$ \\
\hline \multirow{2}{*}{$\begin{array}{l}\text { Student's } \\
\text { reputation }\end{array}$} & $33.8 \%$ & $33.3 \%$ & 0.005 & 0.941 & - & - & - \\
\hline & 312.55 & 308.24 & - & - & 21419.0 & -0.240 & 0.811 \\
\hline \multirow{2}{*}{$\begin{array}{l}\text { Experienced } \\
\text { harm }\end{array}$} & $29.5 \%$ & $25.0 \%$ & 0.677 & 0.411 & - & - & - \\
\hline & 314.51 & 294.96 & - & - & 20356.5 & -1.136 & 0.256 \\
\hline \multirow{2}{*}{$\begin{array}{l}\text { Intervention } \\
\text { measures }\end{array}$} & $67.8 \%$ & $82.5 \%$ & 7.157 & $0.007 * *$ & - & - & - \\
\hline & 302.71 & 375.07 & - & - & 16674.5 & -3.361 & $0.001 * *$ \\
\hline \multirow{2}{*}{$\begin{array}{l}\text { Experience } \\
\text { at school }\end{array}$} & $29.1 \%$ & $26.3 \%$ & 0.276 & 0.599 & - & - & - \\
\hline & 313.69 & 300.56 & - & - & 20805.0 & -0.611 & 0.541 \\
\hline \multirow{2}{*}{$\begin{array}{l}\text { Reaction } \\
\text { and } \\
\text { behaviour }\end{array}$} & $74.4 \%$ & $76.3 \%$ & 0.126 & 0.723 & - & - & - \\
\hline & 310.09 & 324.98 & - & - & 20681.5 & -0.698 & 0.485 \\
\hline
\end{tabular}

Notes: * - statistical significance level $\alpha=0.05$; ** - statistical significance level $\alpha=0.01$. R.v. - average of ranks.

In the dimension "Reaction and behaviour", statistically significant differences between university and non-university students are recorded. Thought insignificantly, university students react stronger to the situation than college students (i.e. inform the responsible persons or just the persons working at higher education institution and not related to the course/group directly; tell course/group fellows to whom they are in good relationship, also to friends outside the higher education institution and family members). 


Harassment and Bullying among Students in Higher Education Institutions:
Manifestation of Single Cases of Harassment
and Bullying in Aspects of Demographic Variables

\section{Discussion}

This study investigated Lithuanian universities and colleges students' involvement into traditional forms of bullying. The results of the performed research determined that $18.5 \%$ of the persons under research $(\mathrm{N}=115)$ experience bullying, i.e., negative actions of study fellows, which continue not less than 6 months and at least once a week. These data coincide with the results of other, though quite rare, researches indicating the existence of the phenomenon in higher education. However, prevalence rates of harassment and bullying fluctuate in various researches. Such fluctuations might be determined by a number of factors, including what definition is used or what repeatability is considered as bullying already (Smith, 2016). Different data might be determined by both the used research methodology, and socio-cultural or economic environment of the researched set (Sánchez et al., 2016). The research of Porhola et al. (2016), which analysed a prevalence of bullying in higher education of different countries, could be mentioned as example. This research revealed quite different number of students who suffered bullying from their fellow students, which fluctuates from $2 \%$ in Estonian higher education to $25 \%$ in higher education of Argentina. Peer bullying was also determined in higher education institutions of other countries - they are suffered by $5 \%-7 \%$ of Finnish students (Sinkkonen, Puhakka and Meriläinen, 2014), about 15\% of Chinese students (Cao, Wei and Cai, 2017). Researches performed in USA also point out this phenomenon, however, the number of students suffering bullying fluctuates from 11\% (Porhola et al., 2016) to $27 \%$ (Perry and Blincoe, 2015), depending on the research. The research performed in Turkey, Pamukkale University, also indicates that students suffer bullying and harassment and that is pointed out by $25.4 \%$ of the researched students (Serinkan et al., 2013). Even greater number of persons under research from southeast of Spain college - $62.2 \%$ - indicate that they faced the phenomenon (Sánchez et al., 2017).

In this research, prevalence of single cases of harassment and bullying in inter-relationship was analysed with reference to the dimensions distinguished by Vveinhardt (2017): communication, personal reputation, student's reputation, experienced harm, intervention measures, experience at school and reaction and behaviour in groups. The results obtained were compared in aspects of students' age, gender and study cycle.

While discussing manifestations of harassment and bullying in higher education, attention often is paid to students' previous experience of participation in bullying process. Usually it is related to understanding that bullying does not disappear with age, i.e. with reference to Social Learning Theory, the person might repeat negative behaviour that was rewarded previously (Curwen, McNichol and Sharpe, 2011). It is also influenced by knowledge that those, who are with histories of bullying, have big difficulties to adapt to the environment of higher education institution (Holt et al., 2014), and there exists high enough prevalence of traditional bullying and harassment at schools that sometimes reaches 89.6\% (Modecki et al., 2014).

This research revealed that male, students of higher education institutions, are the ones having higher negative experience related to bullying and harassment at secondary school. That means, male students stated that they suffered more bullying at school, saw more cases of bullying, when they kept out of the conflict in order to avoid suffering, or just paid no attention. However, comparison of such results with the results of other authors is complicated because the researches point out discrepant results. Though many researchers state that boys of different age should be considered as being at risk for involvement in bullying both as bullies, and as victims (Smith, 2016; Jormanainen et al., 2014; Iossi Silva et al., 2013; etc.), other researches tend to distinguish girls as the ones more often suffering from bullying (Malecki et al., 2015; Schneider et al., 2012). 
In this research, male students, though they had more negative experience at school, were not the ones who suffered bullying and harassment at higher education institution statistically more often than women. The research also revealed that women also are not the persons under research who indicate facing bullying more often than men. Other researches performed in higher education institutions demonstrate discrepant results. The research of Pontzer (2010) determined that it is men who could be distinguished as a gender that more often participates in traditional bullying and harassment both as bully, and victim of bullies. However, other researches do not determine relationship between students' gender and being a victim of traditional bullying (Wensley and Campbell, 2012), or determine significantly higher numbers of female students at higher education institutions who suffered bullying (Meriläinen, Puhakka and Sinkkonen, 2015). Although, in the latter case, a reliable difference in aspect of gender is not determined as well. In this context, such results also could be explained by composition of the researched sample, where usually women are dominating (Sinkkonen et al., 2014; Goodboy, Martin and Goldman, 2016). Also, there are the ones believing that, while analysing bullying, differences of genders disappear after reaching the age of young adult (Glass and Fireman, 2016).

Thus, in the environment of higher education institution, distinguishing of gender as involvement into bullying and harassment risk factor remains debatable for a while, and that supposes the necessity for further researches. Also, not only previous experience should be taken into account, but proportions of genders in higher education should be assessed as well.

While analysing responses of students experiencing bullying and harassment in interrelationship considering age groups and dimensions, it was determined that younger respondents in comparison to older ones point out that they more often face difficulties in communication - they are more often being sneered, threatened, ignored in interrelationship. The research of Pontzer (2010) also points out higher involvement of younger students as victims into the bullying process, which also determined a relation of such victims' number with being a bullying victim in childhood. Significantly higher participation of younger students in bullying and harassment could be related to their transition from secondary school to higher education institution, since other researches also point out that some bullying peaks are determined at the stages of school transition, namely (Wang et al., 2016). Transition to higher education institution often raises high requirements for formation of new social connections. Some are trying to establish themselves in the new social hierarchy or to maintain social status they had at school (Rospenda et al., 2013), and others, especially those who suffered school bullying and had difficulty in peer relationships, are likely to demonstrate weaker peer relationships and more difficult development of any relationship (Holt et al., 2014).

It also could be stated that a considerable number of younger students who faced difficulties in relationship could be the ones who felt the lack of familial social support during the initial adjustment to the higher school. And, according to the researches, such support might protect previously bullied first-year students from various consequences of negative inter-relationship (Reid et al., 2016). Differences in age aspect could also be explained by analysing a learning environment of higher education institution, which could be named as non-compulsory learning environment. It is stated that namely such environment, contrary than hierarchical nature of many schools, often creates no conditions to stimulate bullying (Coleyshaw, 2010). And the older the students, which is most often related to their transition both to higher course and higher study cycle, the better they are able to use this environment in striving for learning goals and adapting it to personal needs. Including the attempt to avoid bullying and harassment. 
However, younger students, though suffering difficulties in communication, compared to the older (26-year-old and older) ones less emphasize the need for intervention measures that eliminate bullying and harassment or reduce their impact. It is also confirmed by data analysis according to study cycles - the need for intervention measures is more emphasized by master students who are likely older than bachelor students.

Quite weak need for intervention measures at higher education institution can be related to failures in their adapting in a school environment. Most programmes of bullying prevention preformed at the extent of Lithuania first of all are oriented only towards schools that perform primary and basic education programmes. Second, programmes are often selected that are not originally created, but simply adapted (Prakapas and Liubeckaite, 2013). However, efficiency of application of bullying prevention programmes, created and successfully working in other countries, might be debatable in another context and other social environment (Olweus and Limber, 2010). Most likely, one of the consequences is the fact that education services provided in Lithuania are not always targeted towards pupil's well-being and do not fully ensure emotional, social and physical security (Trakšelys and Martišauskienè, 2016). It is also confirmed by data of different researches performed in Lithuania - about $40 \%$ of teenagers are stating that they are not receiving a required teacher's emotional support (Petrulytè and Guogiené, 2017), teenagers also do not believe that in case of assault they will get help, and something will be changed (Gumuliauskienè, Juodaitytè and Malinauskienè, 2010). Still, a considerable number of teacher's state that they feel a lack of abilities allowing to tackle cases of peer bullying at school (Klanienè, Šmitienè and Vaitelytè, 2016).

Unfortunately, such young person's experience acquired at school forms a certain system of beliefs and provisions. However, it is likely that non-compulsory learning environment and system of comprehensive support to students, which is developed in higher education institutions recently, and which help fulfilling student's emotional, academical and social needs and create presumptions to ensure student's personal well-being and study success (Sajiene and Tamuliené, 2012) gradually change students' beliefs regarding the need for intervention measures as well.

Analysing data of the dimension "Intervention measures" in aspect of gender, it was revealed that the position of women regarding the need of intervention measures at higher education institutions is expressed stronger than that of male students. Women also more often and more emotionally react to bullying, more often apply for help than men. In this regard, the results of the performed research correspond to those of Meriläinen, Puhakka and Sinkkonen (2015), who, by analysing students' suggestions for eliminating bullying pointed out that women are more supportive in striving to understand and help to those who experienced assaulting behaviour. Women, as the ones who more often take the role of defenders, are distinguished by others as well (Smith, 2016), and school researches (Hunter and Boyle, 2004) distinguish masculine gender namely as the one less applying to teachers concerning bullying and seeking for help both for themselves and others.

All mentioned results of this research indicate that in Lithuanian higher education, in particular dimensions, bullying manifests, and its prevalence may vary depending on students' gender, age and course. These results also may help to forecast which students with reference to their gender and age might become potential victims of bullying. By forecasting possible manifestations of bullying, the previous experience of school bullying should also be assessed, because „,bullying experiences at school play an important role in students motivation to continue their education at college" (Goodboy, Martin and Goldman, 2016, p.62). And that 
means that having assessed bullying manifestations between students comprehensively and having selected efficient intervention measures, it would be possible to reduce students' decision to leave higher education institution and to create a study environment as favourable as possible, that would ensure the well-being of all studying persons.

\section{Conclusions}

The research results indicate dynamics of students' groups internal and inter-group relationship with respect to age as one of the key factors in case of single cases of harassment and bullying. In this case, there is important a provision of older respondents by perceiving the need to manage negative aspects of inter-relationship by using intervention measures. Also, higher trust in external measures of relationship management is typical to women, whereas men, who had higher experience of negative relationships at school, are more tended to tackle them on their own. This makes a basis to state that the sexuality factor determines the fact that part of the conflicts don't reach public institutional level and remain hidden. There also exists a dependence between reports on single cases of harassment and bullying and the level of education provided by higher education institution, as well as cycles of studies. Students of universities and older students of second cycles of universities (masters) tend to report more on the destructive behaviour of colleagues, more efficiently tackle arising problems of inter-relationship on the basis of external help of third persons. Lack of such preparation or competence can be related to the fact that more often bullying cases (exclusively in the area of personal reputation) and appealing to external help sources are in the younger and lower cycle studies students' groups.

\section{Research limitations and further research}

Although the situation is well revealed by the research results, however, they reflect only the reactions of students of Lithuanian higher education institutions (higher education colleges and universities) within the limit of such criteria as age, gender, type of the higher education institution where one's study, study cycle. While developing the research, it would make a sense to incorporate wider criteria that reflect the diversity of students, and also to assess efficiency of higher education institutions' policy against harassment and bullying. It could be performed within inter-cultural analysis between few European and other countries.

\section{Acknowledgement}

We thank our colleagues who helped organize the study in various higher education institutions.

\section{References}

Adams, F. D. and Lawrence, G. J., 2011. Bullying victims: The effects last into college. American Secondary Education, 40(1), pp.4-13.

Aleid, A. S., 2016. The Effectiveness of Student Extracurricular Activities in Evaluating Violent Behavior among Students in the Preparatory Year at Hail University. Journal of Education and Practice, 7(18), pp.32-43. 
Betts, L. R., Gkimitzoudis, A., Spenser, K. A. and Baguley, T., 2016. Examining the roles young people fulfill in five types of cyber bullying. Journal of Social and Personal Relationships, [e-journal] 34(7), pp.1080-1098. https://doi-org.ezproxy.vdu.lt:2443/ 10.1177/0265407516668585.

Birks, M., Budden, L. M., Biedermann, N., Park, T. and Chapman, Y., 2018. A 'rite of passage?': Bullying experiences of nursing students in Australia. Collegian, [e-journal] 25(1), pp. 45-50. http://dx.doi.org/10.1016/j.colegn.2017.03.005.

Blood, G. W. and Blood, I. M., 2016. Long-term Consequences of Childhood Bullying in Adults who Stutter: Social Anxiety, Fear of Negative Evaluation, Self-esteem, and Satisfaction with Life. Journal of Fluency Disorders, [e-journal] 50, pp.72-84. 10.1016/j.jfludis.2016.10.002.

Cao, J., Wei, S. and Cai, M., 2017. Investigation of influential factors of academic and psychological distress in university students. Biomedical Research, 28(5), pp.2174-2179.

Celik, S. S. and Bayraktar, N., 2004. A study of nursing student abuse in Turkey. Journal of Nursing Education, 43(7), pp.330-336.

Chekwa, C., Thomas Jr. E. and Jones, V. J., 2013. What Are College Students' Perceptions about Campus Safety? Contemporary Issues in Education Research, 6(3), pp.325-332.

Coleyshaw, L., 2010. The power of paradigms: A discussion of the absence of bullying research in the context of the university student experience. Research in PostCompulsory Education, [e-journal] 15(4), pp.377-386. https://doi.org/10.1080/ 13596748.2010.526799.

Cooper, J. R., Walker, J., Askew, R., Robinson, J. C. and McNair, M., 2011. Students' perceptions of bullying behaviours by nursing faculty. Issues in Educational Research, 21(1), pp.1-21.

Cornell, D., Gregory, A., Huang, F. and Fan, X., 2013. Perceived prevalence of teasing and bullying predicts high school dropout rates. Journal of Educational Psychology, 105(1), pp.138-149.

Curwen, T., McNichol, J. S. and Sharpe, G. W., 2011. The progression of bullying from elementary school to university. International Journal of Humanities and Social Science, 1(13), pp.47-54, [online] Available at: <http://www.ijhssnet.com/journals/ Vol_1_No_13_Special_Issue_September_2011/7.pdf > [Accessed 20 January 2017].

DeSouza, E. R., 2010. Frequency Rates and Correlates of Contrapower Harassment in Higher Education. Journal of Interpersonal Violence, [e-journal] 26(1), pp.158-188. https://doi-org.ezproxy.vdu.lt:2443/10.1177/0886260510362878.

DeSouza, E. R. and Ribeiro, J., 2005. Bullying and Sexual Harassment among Brazilian High School Students. Journal of Interpersonal Violence, [e-journal] 20(9), pp.10181038. https://doi-org.ezproxy.vdu.lt:2443/10.1177/0886260505277731.

Glass, D. J. and Fireman, G. D., 2016. College Aggression and Prosociality as Social Strategies. NEEPS Special Issue, pp.50-72.

Goodboy, A. K., Martin, M. M. and Goldman, Z. W., 2016. Students' experiences of bullying in high school and their adjustment and motivation during the first semester of college. Western Journal of Communication, [e-journal] 80(1), pp.60-78. https://doi.org/10.1080/10570314.2015.1078494. 
Gumuliauskienė, A., Juodaitytė, A., and Malinauskienė, D., 2010. Research-based searches for violence and bullying prevention possibilities. Teacher Education, 14(1), pp.194-207.

Hagenauer, G. and Volet, S. E., 2014. Teacher-student relationship at university: an important yet under-researched field. Oxford Review of Education, [e-journal] 40(3), pp.370-388. 10.1080/03054985.2014.921613.

Hoel, H., Zapf, D. and Cooper, C. L., 2002. Workplace bullying and stress. In: L. Pamela, D. Perrewe and C. Ganster, eds. 2002. Historical and Current Perspectives on Stress and Health (Research in Occupational Stress and Well-being). Volume 2. S.1: Emerald Group Publishing Limited, pp.293-333.

Holt, M. K., Greif Green, J., Reid, G., DiMeo, A., Espelage, D. L., Felix, E. D., Furlong, M. J., Poteay V. P. and Sharkey, J. D., 2014. Associations between past bullying experiences and psychosocial and academic functioning among college students. Journal of American College Health, [e-journal] 62(8), pp.552-560. 10.1080/07448481.2014.947990.

Hong, J. S., Kral, M. J. and Sterzing, P. R., 2014. Pathways from Bullying Perpetration, Victimization, and Bully Victimization to Suicidality among School-Aged Youth: A Review of the Potential Mediators and a Call for Further Investigation. Trauma, Violence, \& Abuse, [e-journal] 16(4), pp.379-390. https://doi-org.ezproxy.vdu.lt: 2443/10.1177/1524838014537904.

Hunter, S. C. and Boyle, J. M. E., 2004. Appraisal and coping strategy use of victims of school bullying. British Journal of Educational Psychology, [e-journal] 74(1), pp.83107. 10.1348/000709904322848833.

Iossi Silva, M. A., Pereira, B., Mendonça, D., Nunes, B. and Oliveira, W. A. D., 2013. The involvement of girls and boys with bullying: an analysis of gender differences. International Journal of Environmental Research and Public Health, [ejournal] 10(12), pp.6820-6831. 10.3390/ijerph10126820.

Jantzer, A. M. and Cashel, M. L., 2017. Bullying Victimization, College Adjustment, and the Role of Coping. Journal of College Student Development, [e-journal] 58(2), pp. 283 289. 10.1353/csd.2017.0020.

Jormanainen, E., Fröjd, S., Marttunen, M. and Kaltiala-Heino, R., 2014. Is pubertal timing associated with involvement in bullying in middle adolescence? Health Psychology and Behavioral Medicine: An Open Access Journal, [e-journal] 2(1), pp.144-159. 10.1080/ 21642850.2014.881259.

Kang, L. S. and Sidhu, H., 2015. Identification of Stressors at Work: A Study of University Teachers in India. Global Business Review, [e-journal] 16(2), pp.303-320. https://doiorg.ezproxy.vdu.lt:2443/10.1177/0972150914564421.

Klanienè, I., Šmitienè, G. and Vaitelytè, R., 2016. Opportunities for improvement teachers'competence to carry out the prevention of bullying among pupils at school. Education in a Changing Society, 1, pp.5-12.

Kyriacou, C., Mylonakou-Keke, I. and Stephens, P., 2016. Social pedagogy and bullying in schools: the views of university students in England, Greece and Norway. British Educational Research Journal, 42(4), pp.631-645.

Lund, E. M. and Ross, S. W., 2016. Bullying Perpetration, Victimization, and Demographic Differences in College Students A Review of the Literature. Trauma, Violence, \& Abuse, [e-journal] 18(3), pp.348-360. 10.1177/1524838015620818. 
Malecki, C. K., Demaray, M. K., Coyle, S., Geosling, R., Rueger, S. Y. and Becker, L. D. 2015. Frequency, Power Differential, and Intentionality and the Relationship to Anxiety, Depression, and Self-Esteem for Victims of Bullying. Child \& Youth Care Forum, 44(1), p. 115.

Marraccini, M. E., Weyandt, L. L. and Rossi, J. S., 2015. College students' perceptions of professor/instructor bullying: questionnaire development and psychometric properties. Journal of American College Health, [e-journal] 63(8), pp.563-572. http://dx.doi.org/10.1080/07448481.2015.1060596.

Meriläinen, M., Puhakka, H. and Sinkkonen, H. M., 2015. Students' suggestions for eliminating bullying at a university. British Journal of Guidance \& Counselling, 43(2), pp. 202-215.

Modecki, K. L., Minchin, J., Harbaugh, A. G., Guerra, N. G. and Runions, K. C., 2014. Bullying prevalence across contexts: A meta-analysis measuring cyber and traditional bullying. Journal of Adolescent Health, [e-journal] 55(5), pp.602-611. 10.1016/ j.jadohealth.2014.06.007.

Monks, C. P., Smith, P. K., Naylor, P., Barter, C., Ireland, J. L. and Coyne, I., 2009. Bullying in different contexts: Commonalities, differences and the role of theory. Aggression and Violent Behavior, [e-journal] 14(2), pp.146-156. https://doi.org/ 10.1016/j.avb.2009.01.004.

Myers, C.-A. and Cowie, H., 2017. Bullying at University: The Social and Legal Contexts of Cyberbullying Among University Students. Journal of Cross-Cultural Psychology, [e-journal] 48(8), pp.1172-1182. https://doi-org.ezproxy.vdu.lt:2443/10.1177/ 0022022116684208 .

Nishina, A., Juvonen, J. and Witkow, M. R., 2005. Sticks and stones may break my bones, but names will make me feel sick: The psychosocial, somatic, and scholastic consequences of peer harassment. Journal of Clinical Child and Adolescent Psychology, [e-journal] 34(1), pp.37-48. 10.1207/s15374424jccp3401_4.

Olweus, D. and Limber, S., 2010. The Olweus Bullying Prevention Program: Implementation and evaluation over two decades. In: S. Jimerson, S. Swearer and D. Espelage, eds. 2010. Handbook of Bullying in Schools: An International Perspective. New York: Routledge, pp. 377-401.

Palaz, S., 2013. Vertical Bullying in Nursing Education: Coping Behaviors of Turkish Students. International Journal of Nursing Education, 5(1), pp.193-197.

Patchin, J. W. and Hinduja, S., 2015. Measuring cyberbullying: Implications for research. Aggression and Violent Behavior, [e-journal] 23, pp.69-74. http://doi.org/10.1016/ j.avb.2015.05.013.

Patton, D. U., Hong, J. S., Patel, S. and Kral, M. J., 2017. A systematic review of research strategies used in qualitative studies on school bullying and victimization. Trauma, Violence, \& Abuse, [e-journal] 18(1), pp.3-16. 10.1177/1524838015588502.

Perry, A. D. and Blincoe, S., 2015. Bullies and Victims in Higher Education: A MixedMethods Approach. Journal of Bullying and Social Aggression, [online] Available at: <http://sites.tamuc.edu/bullyingjournal/article/bullies-and-victims-in-highereducation/> [Accessed 17 January 2017]. 
Petrulytè, A. and Guogienè, V., 2017. Paauglių psichologinès sveikatos vertinimas vykdant tiriamają ir prevencinę veiklą, Pedagogika / Pedagogy, 126(2), pp.99-114.

Pickel, K. L. and Gentry, R. H., 2017. Slut Shaming in a School Bullying Case: Evaluators Ignore Level of Harm When the Victim Self-Presents as Sexually Available. Sex Roles, [e-journal] 76(1-2), pp.89-98. https://doi.org/10.1007/s11199-016-0662-6.

Piotrowski, C. and King, C., 2016. The enigma of adult bullying in higher education: a research-based conceptual framework. Education, 136(3), pp.299-306.

Pontzer, D., 2010. A theoretical test of bullying behavior: parenting, personality, and the bully/victim relationship. Journal of Family Violence, [e-journal] 25(3), pp.259-273. https://doi.org/10.1007/s10896-009-9289-5.

Prakapas, R. and Liubeckaitė J., 2013. Patyčių prevencijos išgrynintoje gimnazijoje bruožai. Socialinis darbas, 12(1), pp.109-120.

Reid, G. M., Holt, M. K., Bowman, C. E., Espelage, D. L. and Green, J. G., 2016. Perceived social support and mental health among first-year college students with histories of bullying victimization. Journal of Child and Family Studies, [e-journal] 25(11), pp.3331-3341. https://doi.org/10.1007/s10826-016-0477-7.

Rospenda, K. M., Richman, J. A., Wolff, J. M. and Burke, L. A., 2013. Bullying victimization among college students: Negative consequences for alcohol use. Journal of Addictive Diseases, [e-journal] 32(4), pp.325-342.10.1080/10550887.2013.849971.

Sajiene, L. and Tamulienè, R., 2012. Paramos studentams kokybès vertinimo parametrai aukštojo mokslo institucijose. Aukštojo mokslo kokybè, 9, pp.120-139.

Sánchez, F. C., Romero, M. F., Navarro-Zaragoza, J., Ruiz-Cabello, A. L., Frantzisko, O. R. and Maldonado, A. L., 2016. Prevalence and patterns of traditional bullying victimization and cyber-teasing among college population in Spain. BMC Public Health, [e-journal] 1(16), pp.1-10. 10.1186/s12889-016-2857-8.

Sansone, R. A., Leung, J. S., and Wiederman, M. W., 2012. Having been bullied in childhood: Relationship to aggressive behaviour in adulthood. International Journal of Social Psychiatry, [e-journal] 59(8), pp. 824-826. https://doi-org. ezproxy.vdu.lt:2443/10.1177/0020764012456814.

Schneider, S. K., O'donnell, L., Stueve, A. and Coulter, R. W. S., 2012. Cyberbullying, school bullying, and psychological distress: A regional census of high school students. American Journal of Public Health, [e-journal] 102(1), pp.171-177. 10.2105/ AJPH.2011.300308.

Seixas, S. R., Coelho, J. P. and Nicholas-Fischer, G., 2013. Bullies, victims and bullyvictims: Impact on health profile. Educação, Sociedade \& Culturas, 38, pp.53-75.

Serinkan, C., Akşit, İ., Avcik, C., Arat, G. and Alacaoğlu, D., 2013. The Study of Students' Perceptions of Mobbing at Pamukkale University. Procedia-Social and Behavioral Sciences, [e-journal] 89, pp.856-861. https://doi.org/10.1016/j.sbspro.2013.08.944.

Shaw, T., Dooley, J. J., Cross, D., Zubrick, S. R. and Waters, S., 2013. The Forms of Bullying Scale (FBS): validity and reliability estimates for a measure of bullying victimization and perpetration in adolescence. Psychological Assessment, [e-journal] 25(4), pp.1045-1057. 10.1037/a0032955.

Shelley, W. W., Pickett, J. T., Mancini, C., McDougle, R. D., Rissler, G. and Cleary, H., 2017. Race, Bullying, and Public Perceptions of School and University Safety. Journal 
of Interpersonal Violence. [e-journal] First Published October 20, 2017. https://doiorg.ezproxy.vdu.lt:2443/10.1177/0886260517736272.

Sinkkonen, H. M., Puhakka, H. and Meriläinen, M., 2014. Bullying at a university: students' experiences of bullying. Studies in Higher Education, [e-journal] 39(1), pp.153-165. http://dx.doi.org/10.1080/03075079.2011.649726.

Smith, P. K., 2016. Bullying: Definition, Types, Causes, Consequences and Intervention. Social and Personality Psychology Compass, [e-journal] 10(9), pp.519-532. 10.1111/ spc3.12266.

Trakšelys, K. and Martišauskienė, D., 2016. Švietimo paslaugų kokybė: efektyvumas, rezultatyvumas, prieinamumas. Tiltai, 73(1), pp.191-206.

Valls, R., Puigvert, L., Melgar, P. and Garcia-Yeste, C., 2016. Breaking the Silence at Spanish Universities: Findings from the First Study of Violence Against Women on Campuses in Spain. Violence Against Women, [e-journal] 22(13), pp.1519-1539. https://doi-org.ezproxy.vdu.lt:2443/10.1177/1077801215627511.

Van Noorden, T. H., Haselager, G. J., Cillessen, A. H. and Bukowski, W. M., 2015. Empathy and involvement in bullying in children and adolescents: A systematic review. Journal of Youth and Adolescence, [e-journal] 44(3), pp.637-657. 10.1007/s10964-014-0135-6.

Vidu, A., Schubert, T., Muñoz, B. and Duque, E., 2014. What Students Say About Gender Violence Within Universities: Rising Voices From the Communicative Methodology of Research. Qualitative Inquiry, [e-journal] 20(7), pp.883-888. https://doiorg.ezproxy.vdu.lt:2443/10.1177/1077800414537211.

Vveinhardt, J., Fominienè, V. B., Švagždienė, B. and Andriukaitienè, R., 2017. Diagnostics of single cases of harassment and bullying in relationships between students of higher education institutions: intervention measures for the timely identification of the phenomena. Transformations in business \& economics, 3(42), pp. 240-257.

Vveinhardt, J., Fominiene, V. B., Andriukaitiene, R. and Streimikiene, D., (in press). Diagnostics of single cases of harassment and bullying in relationships of students in higher education institutions: verification of questionnaire dimensions. Economic Research-Ekonomska Istraživanja.

Wang, W., Brittain, H., McDougall, P. and Vaillancourt, T., 2016. Bullying and school transition: Context or development? Child Abuse \& Neglect, 51, pp.237-248.

Wensley, K. and Campbell, M. A., 2012. Heterosexual and nonheterosexual young university students' involvement in traditional and cyber forms of bullying. Cyberpsychology, Behavior, and Social Networking, 15(12), pp.649-654. 